\title{
ENVIRONMENTAL CONSEQUENCES OF URBAN EXPANSION: CASE STUDY OF ENVIRONMENTAL LICENSING PROCESSES IN THE MUNICIPALITY OF GOVERNADOR VALADARES
}

\author{
Sara Carolina Soares Guerra Fardin ${ }^{1 *}$, Talita Jardim do Nascimento ${ }^{2}$, Henrique Delboni Fardin ${ }^{3}$ \\ ${ }^{1}$ Instituto Federal de Educação, Ciência e Tecnologia do Espírito Santo, Avenida Vitória, 1729, 29090-0990, Vitória, \\ Brazil \\ ${ }^{2}$ Instituto Federal de Educação, Ciência e Tecnologia de Minas Gerais, Avenida Minas Gerais, 5189, 35057-760, \\ Governador Valadares, Brazil \\ ${ }^{3}$ Departamento de Edificações e Rodovias, Avenida Marechal Mascarenhas de Moraes, 1501, 29051-015, Vitória, Brazil \\ *Corresponding author: scsguerra@gmail.com

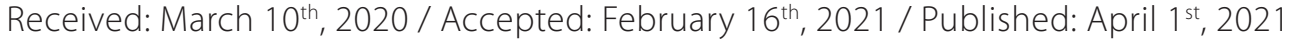 \\ https://DOI-10.24057/2071-9388-2020-53
}

\begin{abstract}
Urban growth is often accompanied by significant environmental changes, which include modification of the natural landscape and the problems related to it, such as real estate speculation, marginalization of the population, landslide risks, flooding, as well as pressure on environmentally protected areas. Therefore, it is necessary to understand how will new urban development affect the already modified space without generating further environmental problems. The research aimed to analyse five projects of allotments in Governador Valadares/Brazil between 2015 and 2017. Besides the information on the projects themselves, geographic information systems (GIS) were used along with laws and bibliography. The biggest obstacle observed was the lack of standardization in the process required by the City Hall, which culminated in projects with different characteristics, including those that did not present important analyzes, such as the Civil Construction Waste Management Plan. It is necessary to move forward in discussions related to urban environmental sustainability, standardizing the possible actions, not only in the municipality of Governador Valadares.
\end{abstract}

KEY WORDS: environmental impact assessment; sustainable city growth; urban planning; environmental urban planning

CITATION: DR. Sara Carolina Soares Guerra Fardin, Talita Jardim do Nascimento, Henrique Delboni Fardin (2021). Environmental Consequences Of Urban Expansion: Case Study Of Environmental Licensing Processes In The Municipality Of Governador Valadares. Geography, Environment, Sustainability, Vol.14, No 1, p. 142-151 https://DOI-10.24057/2071-9388-2020-53

Conflict of interests: The authors reported no potential conflict of interest.

\section{INTRODUCTION}

In the second half of the twentieth century with the growth of the economy and the creation of numerous jobs in the cities, the Brazilian population started the movement of internal migration, leaving the countryside and settling in the cities. During this period, Brazilian cities grew enormously and soon they concentrated around 50\% of the country's population (Grostein 2001).

This process culminated in the formation of large urban centers, which has led to several negative consequences, such as real estate speculation, marginalization of the population, landslide risks, flooding, as well as pressure on environmentally protected areas (Alberto 2009; Stanganini \& Lollo 2018).

In order to fulfil the population demands, the civil construction sector increased enormously. The sector started to influence the dynamics of cities, either by consolidating the pattern of urbanization marked by environmental problems or by creating new concepts of urban development in which environmental and safety standards are placed as differentials against traditional forms of construction. The first, without taking into account existing environmental standards repeatedly go through attempts of adaptation in processes of land tenure regularization, implementation or adaptation of urban afforestation. The second is usually the result of projects that claim to emerge from a sustainable base. But what makes these ventures sustainable or not?

In that context, some macro policies have been developed in Brazil in an attempt to remedy the existing problems in the urban environment such as the Statute of Cities in 2001. The norm aimed to consolidate the role of municipalities as agents that promote the adoption and implementation of the instruments to optimize and boost the development of urban areas, such as the Master Plan and Environmental Zoning, as well as others that aim to ensure the sustainability of processes, such as the Environmental Impact Assessment for projects in the urban area (Brazil 2001).

The Forest Code itself (Federal Law No. 12,651 / 2012 - Brazil 2012) brings important considerations about the importance of environmental preservation in rural and urban areas but fails to define how permanent preservation areas in urban areas should be treated. 
Other regulations, like the Resolution of the National Environment Council (CONAMA) No. 369 (BRAZIL 2006), try to standardize the cases in which there may be an intervention in permanent preservation areas (APP). However, the overlap or gaps in the legislation allows different interpretations which ends up limiting the effective application of normative instruments (Fardin et al. 2018).

The concern with these problems reached such a point that it became the subject of discussion at United Nations conferences and was later included as one of the Sustainable Development Goals (SDGs), particularly SDG 11. The objective establishes that urban areas must reinforce planning instruments at different scales, reducing the impact on the environment, ensuring resilience for cities and better quality of life for the population.

The guarantee of the existence of sustainable cities comes up against the very definition of sustainability. Heloisa Costa, when discussing concepts related to environmental sustainability, states:

it can be said that the concept of sustainable development has been transformed into a huge «umbrella», capable of harboring a wide range of innovative, progressive proposals / approaches, or that, at least, move in the direction of greater social justice, improvement of the population's quality of life, more dignified and healthier environments, commitment to the future. Such comprehensiveness, if, on the one hand, has the merit of «basing» initiatives and proposals from different origins, on the other, by showing the imprecision of the concept, it tends to trivialize it, to transform it into a piece of rhetoric and, therefore, unsustainable by definition. (Costa 1999 p. 8)

Urbanization involves legal, administrative, environmental and social aspects, which should, at least in theory, go together in order to guarantee sustainability, especially in the development of new urban areas. Brazil already has some legislation that aims to guarantee such improvement, particularly Federal Law no. 10.257 / 2001, which creates the City Statute, and Federal Law no. 6.766 / 1979, which regulates the division of urban land (Brasil 1979 \& 2001). All those laws and regulations together are used in the Environmental Impact Assessment of urban allotments.

The different interpretation of the procedure and analysis of environmental impact assessment has direct consequences on the environment. Ribeiro \& Vasconcellos Junior question «what is the extension of the failures and flaws of the AIA that affect its effectiveness in the Brazilian environmental licensing process»?

The Guide «How to build more resilient cities», a document published by the United Nations, does not give details on what it considers to be sustainable development, stating that each city should build this concept based on the existing context (United Nations 2012). In this state of uncertainty about which concept would be more appropriate, this work, however, does not intend to define that concept.

Silveira et al. (2020) point that, although the sustainability concept is not very well defined, to accomplish long term economic and environmental stability it is necessary to integrate and acknowledge concerns about economic, environmental and social consequences. Besides, urban expansion needs to be supported by other policies. Standards should be well defined and analysed in all fields (Amado 2018)

In this context, it becomes necessary to gather information that can support the future development of this important concept that can impact not only the environment but also the safety of those who live in cities. In this sense, the present work sought to analyse the processes of environmental impact assessments of allotments in Governador Valadares during the period from 2015 to 2017. The highlights were correlated to urban sustainability in order to understand the impact of the projects' approval at the city scale. The study also aims to contribute to the reflection on the importance of clearer definitions in environmental policy worldwide.

\section{MATERIALS AND METHODS}

The study has been developed based mainly on the analyses of five impact assessment studies of allotments located in Governador Valadares/MG/Brazil. Along with the study of the existing research and the analysis of secondary data from the study area, this information was used to reflect the impact of urban growth on the environment and sustainability.

The process of research included the following stages:

- First, relevant data were gathered from bibliographic research, starting with laws (federal, state and municipal), city documents and other legal papers. Information from the existing research literature was also analysed, which allowed to compare the Brazilian Standards with other studied areas;

- After that, the study period of two years was selected due to the large number of documents that were included in each assessment, which were also stored in paper at the City Hall. Once the impact assessment projects were chosen, the obtained data were reviewed, summarized and analysed qualitatively. Classes for the analysis were selected based on the correlation to sustainable development and included such parameters as water demand, protected areas and sanitation;

- Also, data containing shapefile maps of the urban area, hydrography and neighbourhoods were gathered from the Brazilian Institute of Geography and Statistics (IBGE) database. These data were integrated, reviewed and processed through GIS (Geographic Information Systems) in order to extract information relevant to the interest areas and correlate it with the data on the allotments;

- Finally, data interpretation and generation of thematic maps were done to obtain the results of the study, based on which certain recommendations were given.

\section{Area description}

The municipality of Governador Valadares was chosen because it is considered a medium-sized city ${ }^{1}$ with a population of 245,125 inhabitants. The selection was also made based on the existing infrastructure, expansion opportunities, goods and services available.

The city initially emerged from an instalment plan, which expanded without proper planning, resulting in several irregular settlements and numerous environmental problems. It suffers from recurrent flooding, even when the rainfall does not occur in the municipality (Genovez et al. 2012; Prefeitura Municipal de Governador Valadares 2015), and is also characterized by high temperatures throughout the year, which creates discomfort for the population.

The city is located in the central watershed region, on the banks of the Doce River, which is its main water source. In 2015 with the collapse of the Fundão tailings dam the city suffered from a lack of water due to the high demand and inability to pump water from the river.

The present study analysed all the licensing processes for the urban subdivisions located in the municipality of Governador Valadares from January 2015 to December 2017, which included a total of five allotment projects (Figure 1), in order to verify if these projects were planned by the entrepreneur and evaluated by the environmental agency on a sustainable and standardized basis.

'Water grant is a term used in Brazil that refers to the right to use a specific amount of water for a determined period of time. 


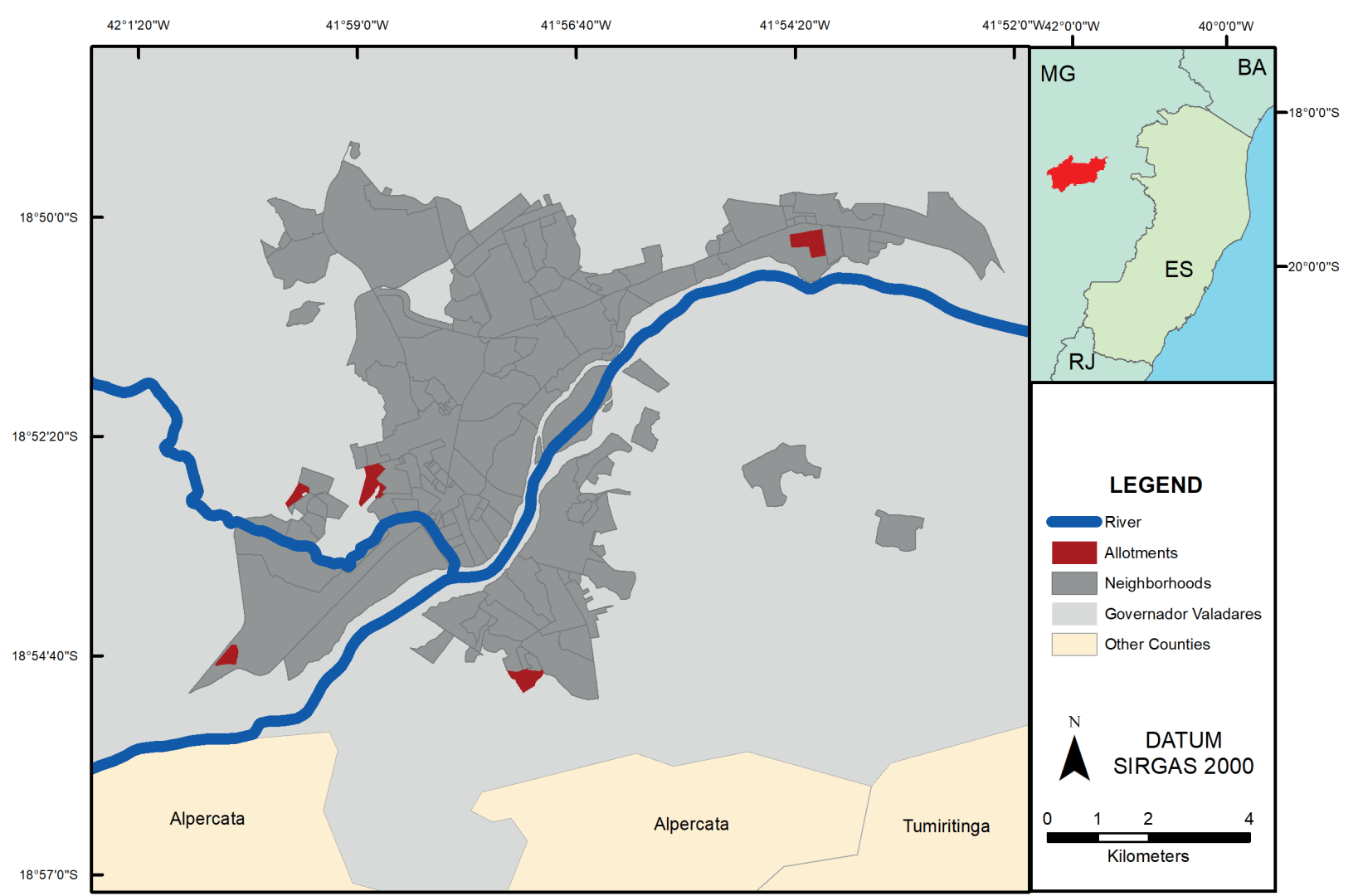

Fig. 1. Location map of the analysed allotments in relation to neighbourhoods in Governador Valadares (MG)

\section{RESULTS}

Allotments impact assessment in governador valadares from 2015 to 2017

To understand the concept of sustainability is important to recognize that it is not relativistic as the Earth's biophysical limits are absolute (Fischer et al. 2007). Based on this statement, various impacts cannot be analysed apart from each other. Another challenge is to adapt to different social, cultural and political contexts, which can be challenging with different impact assessment rules not only in Brazil but in many countries. To illustrate these points, we present the results of five recent impact assessment projects of allotments, analysing not only their effects separately but the combination of all of them.

Integrated water demand planning: pleading for projects $\mathrm{x}$ municipal water grant ${ }^{1}$

In order to estimate the impact of the subdivisions on the city's water demand, calculations were made to identify the volume of water that is spent by the allotments. This calculation took into account the demand per inhabitant per day for residential ${ }^{2}$ and commercial ${ }^{3}$ lots and its results are shown in Table 1.

Table 1. Estimated water demand for the studied allotment projects

\begin{tabular}{|c|c|c|}
\hline VENTURE & LOTS QUANTITY & ESTIMATED VOLUME (L/DIA) \\
\hline 01 & 20 unidades & 8,550 \\
\hline 02 & 476 unidades & 270,368 \\
\hline 03 & 208 unidades & 118,144 \\
\hline 04 & 452 unidades & 256,736 \\
\hline 05 & 211 unidades & 119,848 \\
\hline Total & 1,367 unidades & 776,456 \\
\hline
\end{tabular}

${ }^{1}$ Water grant is a term used in Brazil that refers to the right to use a specific amount of water for a determined period of time.

${ }^{2}$ The calculation was based on the values in Annex C of the Technical Standard of the Basic Sanitation Company of the State of São Paulo (Sabesp) NTS 181 (Basic Sanitation Company of the State of São Paulo 2017) and performed by determining the arithmetic mean between the values water consumption per day stipulated for: residences (95L / per capita / day), luxury residences (165L / per capita / day), apartments without individualization (127.5 L / per capita / day), apartments with individualization ( 100L / per capita / day) and luxury apartment (222.5 $\mathrm{L}$ / per capita / day). This value was multiplied by four, the average number of people in a household estimated by the Brazilian Institute of Geography and Statistics, which gave a total consumption of $568 \mathrm{~L} /$ lot / day (Brazilian Institute of Geography and Statistics 2008). ${ }^{3}$ The calculation was based on the values contained in Annex C of the Technical Standard Sabesp NTS 181 (Basic Sanitation Company of the State of São Paulo 2012) and performed by determining the arithmetic average between the consumption of water day stipulated for: outpatient clinics (22.5 L / service / day), public or commercial buildings ( $40 \mathrm{~L} /$ per capita / day), full-time schools ( $45 \mathrm{~L} /$ per capita / day), boarding schools ( $95 \mathrm{~L} /$ per capita day), schools by term (22 L / per capita / day), offices (40 L / per capita / day), sewing workshops (40 L / per capita day) and auto repair shops ( $75 \mathrm{~L} /$ per capita / day), averaging at $47.5 \mathrm{~L} /$ per capita / day. This value was multiplied by the maximum number of people in a microenterprise (9 employees), just for comparison purposes, which generated a demand of $427.5 \mathrm{~L} /$ lot / day. 
Based on the grants issued by the National Water Agency (ANA) to the municipal water and sewage services concessionaire in the period of execution of the projects, a volume of 2,007,433.98 $\mathrm{m}^{3} /$ day $^{1}$ was granted in the «right to use» category for the city of Governador Valadares. The total sum required by the five allotments is equivalent to $776,456 \mathrm{~L} /$ day or $776.45 \mathrm{~m}^{3}$, which is less than $1 \%$ of the total amount.

However, some questions need to be considered about the existing situation as well as the individual and collective effect of these ventures on the environment. According to Directive 2000/60/EC of the European Parliament, which establishes community actions on water resources policy, when planning the possible uses of water it is necessary to think about the best environmental option, taking into account the technical feasibility and the associated costs to the project (European Union 2000).

In this context, a question about granting of the right to use water for supply arises. Is there a maximum growth limit for a municipality? Would the growth limit be determined by the maximum regional environmental supply range? Growth limits must involve perceptions of risk associated with growth, taking into account favorable and unfavorable scenarios, and involve the population, industries and government in decision-making so that the decision is beneficial to all.

According to the document of Raworth (2012) titled "A safe and just space for humanity», the planet presents growth boundaries that need to be respected, some of which have already been crossed. The relationship is complex as it involves limits that are not always defined by countries' physical barriers but need to be defined in favor of the safety of life on the planet.

Thus, thinking about water demand in isolation no longer makes sense, it needs to be considered in a larger context in order to guarantee the city's resilience. Tucci (2009) states that integrated water management in the urban environment is essential for the development of cities. According to the author, the city is part of a large hydrographic basin, which can be composed of several sub-basins, and needs to be concerned with the water it draws and returns to rivers since these are factors external to the perimeter of the city, but which interact and influence its dynamics and, therefore, need to be analyzed together (Figure 2).

An instrument that can assist in these definitions is the collective granting of water use. In this type of authorization, the right would be granted to a group of users, not just to a beneficiary.

Tamburino et al. (2019) say that when individuals make choices towards collective action there is a better long-term outcome for everyone. Spolidorio (2017) states that negotiated water allocation has the potential to strengthen the processes of water use, generating effective social participation and making the water users regulate themselves.

\section{Municipal sanitation}

With regard to the release of sanitary sewage, the municipality has a right to use grant for this type of release of $13,547.58 \mathrm{~m}^{3} /$ day $^{2}$. If we take into account that $80 \%$ of the collected water is discharged in the form of sewage, the five allotments together generate $621.16 \mathrm{~m}^{3}$ of sewage water per day, which is also little compared to the discharge limit granted.

However, according to the National Water Agency (ANA), in 2013 the municipality of Governador Valadares had $95.4 \%$ of the sewage water collected, but not treated (National Water Agency 2017). Currently, the city has only one sewage treatment plant (ETE), the ETE Santos Dumont, which is still under construction and upon completion should meet about $75 \%$ of the municipality's demand. In this sense, although the discharge may seem insignificant, it will put even more load on a system that is already below the expected environmental conditions.

In this scenario, would it be feasible to ask the entrepreneur to treat the sewage generated by his subdivision? One possible idea would be to create a decentralized sewage treatment system. Some authors point out that decentralized water and sewage systems can offer benefits such as less vulnerability to extreme events, accidents or disasters (Capodaglio 2017), which could contribute to increasing the resilience of a city that is already experiencing problems on a recurring basis.

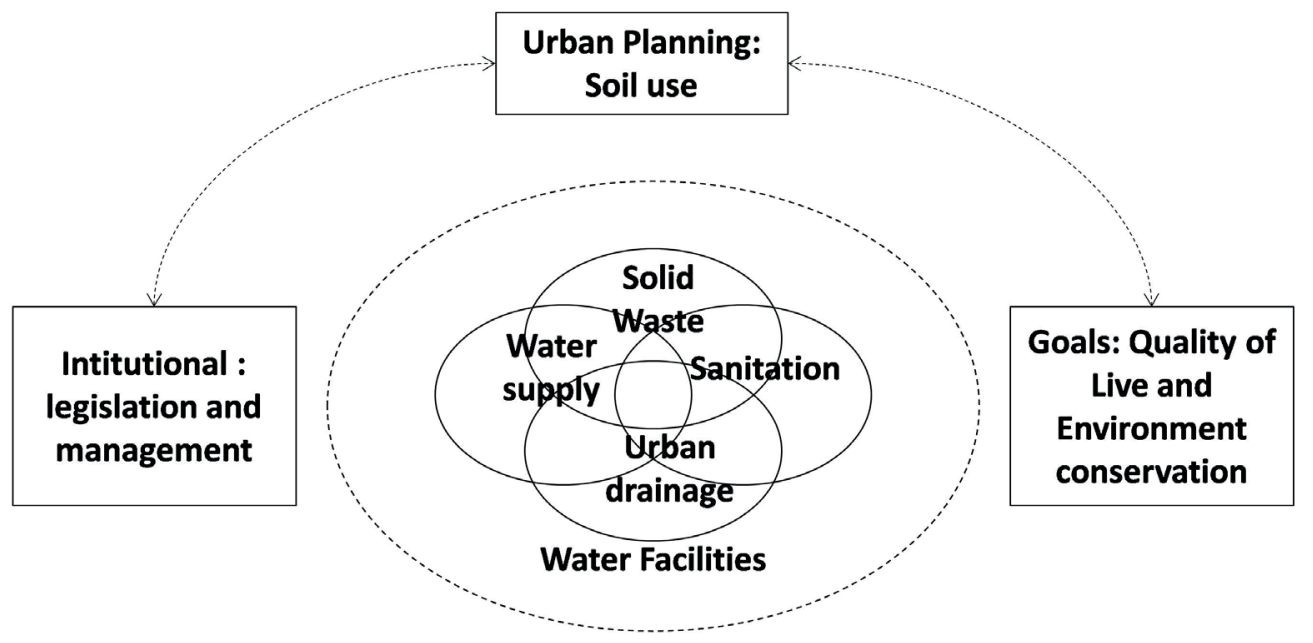

Fig. 2. Components of Integrated Urban Water Management. Source: Tucci (2009)

'Interference codes 817773, 817772, 817755 and 817754, issued on behalf of the Autonomous Water and Sewer Service, in the right to use category. The value given in annual volume in $\mathrm{m}^{3}$ was transformed into daily values for comparison purposes. Available at: http://www.ana.gov.br. [Accessed 20 Oct. 2019].

Interference codes 881061 and 881042, issued on behalf of the Autonomous Water and Sewage Service, in the preventive category type of sewage release. The value given in annual volume in $\mathrm{m}^{3}$ was transformed into daily values for comparison purposes. Available at: http://www.ana.gov.br. [Accessed 10 Oct. 2019]. 
Regarding the costs for implementing the system, it is necessary to compare the costs of treatment in loco with the costs of transport (construction of the network) of this effluent to a possible ETE. Recently, the installation of decentralized systems has become increasingly more attractive, as they use simpler technologies and end up making the systems competitive with affordable cost (Jorsaraei et al. 2014; Capodaglio 2017), however, it needs to be taken into account at the time of project development.

It is worth mentioning that the intent here is not to suggest a way of solving the mentioned problems but to contribute to discussions that may assist in more sustainable growth.

Lower urban density also impacts the costs of installing the needed infrastructure after allotments have already been built (Monkkonen 2013). Besides, when the sewage is released into the public systems, the costs of its treatment are no longer of sellers/buyers become of all the citizens, which is a transference of environmental costs (Braga 2013).

\section{Protected territories: preservation areas, vegetation removal and urban afforestation}

Municipal Complementary Law No. 187/2014 (Prefeitura Municipal de Governador Valadares 2014b) states that intervention in the Permanent Preservation Area (APP) is only allowed in the case of social interest, public utility or low environmental impact. Although one of the developments (05) is located in an area declared by law to be of social interest, there was no request to remove vegetation located in APP.

There was a request to remove vegetation by Allotment 04, but the area is not located in APP. The entrepreneur indicated the existence of an area of $50 \mathrm{~m}^{2}$ with the presence of exotic tree vegetation, Leucaena leucocephala (Lam.) of Wita being the predominant species. Suppression was authorized and the Suppression and Final Destination Report was requested.

Although the size of the area to be removed is small compared to the area of the allotment, it is necessary to analyze the standard adopted by the city which takes into account a larger scale. As stated in several minutes of the Municipal Council for the Defense of the Environment (CONDEMA) ${ }^{1}$, there are also other areas requesting and receiving approval for suppression of vegetation in the municipality.

The suppression of vegetation, although not located in APP, leads to a decrease in the infiltration of rainwater, which may contribute to the occurrence of problems during rainy periods (Fardin, et al. 2018). The removal of vegetation creates even more impermeable surfaces, generating changes in runoff and drainage (Santos \& Haddad 2014). Studies indicate that when green and permeable areas are increased compared to conventional urbanization, it leads to a decrease in peak flow (Tavanti \& Barbassa 2012), which would be extremely beneficial in the case of the municipality of Governador Valadares, considering its flooding history, in addition to several other ecosystem services.
Consequently, regardless of the possibilities for suppression that exist in the legislation, it is essential to consider the dynamics of the water resources existing in the hydrographic basin prior to the approval of a new vegetation suppression.

With regard to urban afforestation, Municipal Law $n^{\circ} 178$ (Prefeitura Municipal de Governador Valadares 2014a) indicates that spaces for public use in the new subdivisions, including leisure and reforested areas, should comprise at least 12\% of the total area of the allotment. The delimitation of these areas can be observed in the Environmental Control Report (RCA) of all allotments.

This distribution of areas leads to questions about the effectiveness of this action. Although the law does not define that the $12 \%$ should be planted in a continuous area, studies indicate that planting trees in impermeable areas imposes stress on the plant, which could be solved with the use of permeable pavement nearby (Mullaney et al. 2015) or by planting continuous areas without the presence of any type of paving. Thus, the suppressed area, although small, would be part of a broader context of ecosystem services. According to Endreny (2018), for every $\$ 1$ invested in urban afforestation, there is an average return of $\$ 2.25$, which does not encompass all the possible benefits generated. The author puts this in number:

London's urban forest is estimated to have $8,421,000$ trees, generating annual benefits of 132.7 million pounds (not including all services), a replacement cost of 6.12 billion pounds and a value for convenience of 43.3 billion pounds. The London study was extrapolated to the megacities of Beijing, Buenos Aires, Cairo, Istanbul, Los Angeles, Mexico City, Moscow, Mumbai and Tokyo and estimated that the annual benefit of forests in these metropolitan areas had an average annual value of US $\$$ 505 million, the potential to achieve nearly $\$ 1$ billion in annual benefits and an additional $\$ 7.9$ billion in total carbon storage value. (Endreny 2018)

Despite the benefits of urban afforestation, which also include improved water infiltration in the soil, increased landscaping, a better sense of well-being by the population and positive changes in the local microclimate, only three of the projects $(01,02$ and 05$)$ stated a plan to plant trees on the sidewalks, although indicating only the minimum presence of $12 \%$ of green areas.

\section{The allotments in relation to the Municipal Zoning and the City Plan}

Complementary Law No. 201/2015 (Prefeitura Municipal de Governador Valadares 2015), which provides guidelines for the use and development of urban and rural land in the municipality of Governador Valadares, establishes that to expand, build or start some type of activity in urban or rural areas of the city, depending on the location of the project, environmental studies may be required by the executive bodies to prevent negative impacts resulting from this implementation. Because of this, the studied allotments were analyzed in order to identify which type of area they occupy (Table 2).

Table 2. Location of the allotment projects under study in relation to the Municipal Zoning of Governador Valadares

\begin{tabular}{|c|c|c|c|}
\hline \multirow{2}{*}{ Venture } & \multirow{2}{*}{ ZONE } & \multicolumn{2}{|c|}{ CHARACTERISTICS } \\
\cline { 3 - 4 } & & LOTS QUANTITY & GOAL \\
\hline 01 & Urban expansion zone & 20 & Commercial \\
\hline 02 & Urban expansion zone & 476 & Residential \\
\hline 03 & Urban expansion zone II & 208 & Residential \\
\hline 04 & Water influence zone & 452 & Residential \\
\hline 05 & Social interest housing zone II & 211 & Residential \\
\hline
\end{tabular}

'Available at: http://www.valadares.mg.gov.br/detalhe-da-materia/info/conselho-municipal-de-defesa-do-meio-ambientecodema/12036. [Access 05 Mar. 2020]. 
Although all the analyzed allotments have environmental studies approved by the city hall, according to the current legislation, every allotment must have a previous study, which indicates the possibility of development in the previously defined location. However, no documents were found to prove the existence of this prior analysis.

Allotments 01, 02 and 03 are located in Urban Expansion areas, these areas are located within or contiguous to the perimeter considered urban and present good natural conditions to be occupied. The legislation states that the urban parameters should be defined at the time of formalizing the request.

Allotment 04 is located in an area defined as the Water Influence Zone and differs from the other areas, as it is located close to the Doce River and is influenced by the rainfall regime during the rainy season (Prefeitura Municipal de Governador Valadares 2015). According to the legislation, these areas must have specific construction criteria that guarantee lower density compared to the other areas of the city and greater permeability between the constructions.

This point needs to be addressed more carefully by the entrepreneur and the licensing agency since, as it was previously said, the municipality has numerous records of floods in its urban perimeter (Genovez et al. 2012; Prefeitura Municipal de Governador Valadares 2015).

In this sense, the projects were analyzed based on a study carried out by the Mineral Resources Research Company in conjunction with the National Water Agency and the Minas Gerais Water Management Institute, which defined the floodplain of the city of Governador Valadares based on previous rainfall observations and application of a hydraulic model (Figure 3).
From this study, it was possible to observe that four out of five analyzed allotments are located within the floodplain of the river, two of them in areas with a high risk of flooding, which, considering a return period of less than ten years, are frequently flooded.

The report, which dates back to 2004, recommends that changes should be made to the municipality's Territorial Zoning, suggesting that in areas with a high chance of flooding there should be only territories intended for public leisure use, such as parks and squares, while the areas with a medium and low possibility of extreme events (TR between 10 and 100 years and TR> 100 years) should be occupied by buildings that do not suffer significant losses in case of a flood event, including houses and commercial establishments (Mineral Resources Research Company 2004). However, despite the recommendations, the City Hall continues to carry out allotment projects in floodable areas.

The flooding problem in the municipality is so recurrent that in a study carried out on the perception of floods by the residents of the municipality, it was shown that the population, although not living in risk areas, signaled some problems related to floods (Amorim et. al. 2018). Affected residents also reported problems such as «bad smell, contamination, disease» and claim that flooding affects the quality of life in the city.

\section{Analysis of expected environmental impacts and adopted measures}

Table 3 presents a summary of the main impacts expected during the installation and operation phase of the studied subdivisions according to the entrepreneur's manifestation in the documents presented and the requirements of the environmental agency.

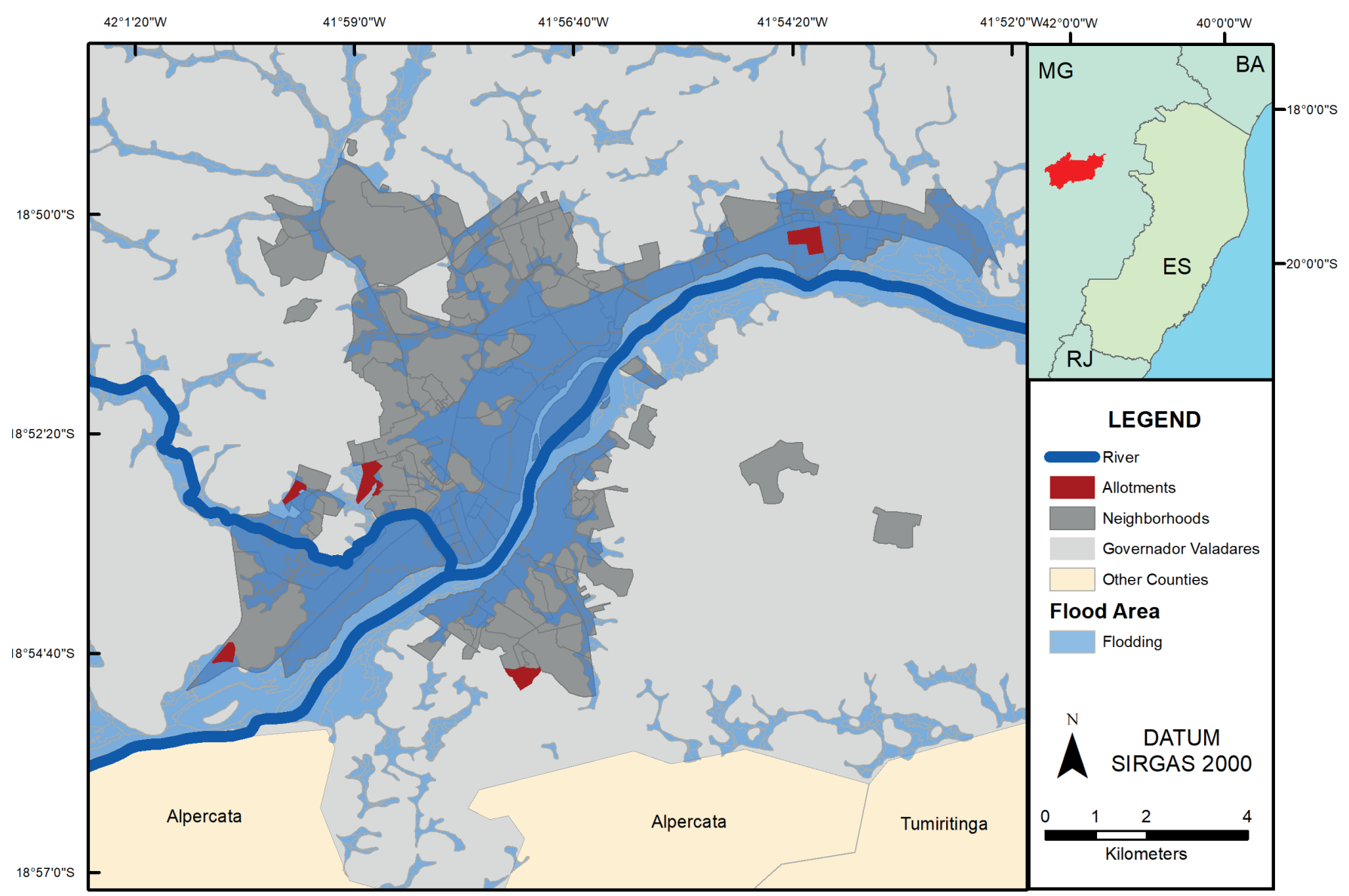

Fig. 3. Floodable channel of the Doce River within the municipality of Governador Valadares, with emphasis on the analysed neighbourhoods under analysis 
Table 3. Main expected environmental impacts in the installation and operation licenses of the analysed subdivisions

\begin{tabular}{|c|c|c|c|c|}
\hline \multicolumn{5}{|c|}{ NEGATIVE IMPACTS } \\
\hline Venture & Soil compaction and erosion & Emission of air pollutants & $\begin{array}{l}\text { Alteration of the } \\
\text { original vegetation }\end{array}$ & $\begin{array}{c}\text { Generation of } \\
\text { construction waste }\end{array}$ \\
\hline 01 & $x$ & $x$ & $x$ & \\
\hline 02 & $x$ & $x$ & $x$ & \\
\hline 03 & $x$ & $x$ & & $x$ \\
\hline 04 & & $x$ & $x$ & \\
\hline 05 & $x$ & $x$ & $x$ & \\
\hline
\end{tabular}

Soil erosion and compaction are characteristic impacts of allotment activities, which are caused by the processes of cleaning the allotment, removing the existing vegetation cover and earthwork procedures (Pereira 2015). Except for allotment 04, the other studies, in addition to mentioning these impacts, attached a list of measures that would be taken to control these processes.

Allotment 04 has not stated that this impact will occur, however, it included procedures similar to those that will be developed in other areas, particularly leveling of the occupied areas with the use of trucks and other earthmoving equipment. Therefore, there remains a doubt regarding the information provided as well as the own analysis of the environmental agencies, which did not take this impact into account.

Roedel \& Dias (2018) when analyzing impact assessment studies of allotments in Brusque/SC also indicated that all of the three projects were going to cause problems related to soil movement, including erosion. It is even more concerning in a city, which was already affected by a massive amount of sediments coming from the disruption of the Fundão dam, and indicates the need to rethink the minimum content of impact assessment for the allotment projects. This is especially important because different views of the professionals who carry out the analysis can lead to different assessments, which may be the result of the professional's training often prioritizing training in their main field at the expense of complementary training for analysis and interpretation of environmental impact assessments (Morgan et al. 2012).

Another environmental impact quite common in allotment projects is the emission of air pollutants in a form of particulate matter. All projects indicate the presence of this impact, particularly during earthmoving processes in the installation phase and from car circulation in the operation phase in which the facilities will be built, while no circumvention measures have been suggested.

Air pollutants control is very important because it affects not only the site but also the entire neighborhood, as harmful substances can be transported far from their original location. If not considered in advance, mitigation or control measures can fail, exposing the population to pollution (Lollo \& Rohm 2009). To reduce this potential impact all the projects suggested sprinkling area with water.

However, none of them suggested anything for the operation phase, indicating that at this point the entrepreneur is not responsible and impacts are controlled by each individual construction site. Although it is permitted according to the legislation, this issue raises some concerns as it is completely different to evaluate one separate construction compared to 476 like in Allotment n. 02. If all the studied allotments are taken into account, the number of new construction sites reaches 1367.
All these activities have great potential for generating waste, especially Civil Construction Waste (RCC). RCC is generated during construction activities, such as land preparation, excavation and other actions that generate material with polluting potential. CONAMA Resolution No. 307 states that this material must be disposed according to the Municipal Construction Waste Management Plan, which «will aim to establish the necessary procedures for the environmentally appropriate handling and disposal of waste» (Conselho Nacional de Meio Ambiente 2002 \& 2012a).

The municipality of Governador Valadares has Complementary Law No. 167/2013 institutes the Plan, which states that the person responsible for generating the waste must carry out its correct characterization, sorting, packaging and transportation (Prefeitura Municipal de Governador Valadares 2013). Even so, only Allotment 03 reported that Civil Construction Waste (CCW) will be generated.

This lack of indication of the generation of waste leads to numerous questions, such as: Who is responsible for the absence of this information in the licensing process, entrepreneur or inspection agency? As a management plan was not indicated, where did this waste go? In the light of current legislation, how to ensure that the next licensing processes are carried out correctly?

These questions are even more relevant when observing the document «Diagnosis of the Situation of the Provision of Sanitation Services, Urban Cleaning and Solid Waste Management», requested in 2015 by the municipality to support the creation of the Municipal Basic Sanitation Plan. In this report, it was found that the municipality's CCW was not properly disposed and that there are numerous points for disposal of clandestine debris since the municipality does not have a sorting and processing plant.

In this context, is important to identify what does the legislation say. However, the existing laws do not cover all environmental aspects included in the precepts of many other technical standards, which are dispersed in numerous normative instruments and require a standardization of methodologies to facilitate the correct application. Rotaru et al. (2019) indicate that standards of environmental monitoring have high importance and should be used in a plan-do-check-act cycle. The disperse standardization creates a new field of expertise, leading to a knowledge monopolization that does not contribute to the mitigation of the environmental stress (Xavier et al. 2019).

Despite this, it seems that land policy-making alternates between restraining practices that exceed the legal framework and unclear laws and policies, which results in ambiguity (Ho 2001) and different outcomes for allotments, community and environment.

Regarding the removal of vegetation, only Allotment 03 does not indicate that it will occur. The environmental consequences of this removal were discussed in the section on protected areas. 
When all parameters are analyzed together, an absence of an interdisciplinary approach can be observed in the process of developing the studied allotments as well as in the analysis by the different management Agencies involved. The responsibility of the Environmental Secretary in the impact assessment is not restricted to green spaces management. However, it has to be integrated with other Agencies, so they can act together pursuing the same goal. According to Arretche (2006), accountability and attribution definition must start individually, defining the collective goal and establishing mechanisms to integrate and coordinate the process. This integration is fundamental for reaching better evaluation practices.

Another problem these scattered approvals generate is an unequal proportion of services since they are concentrated in the city center. With the sprawled area there is more transportation needed causing higher greenhouse gas emission, more land speculation nearby city center and smaller green areas as well as multiple other problems (Polidoro et al. 2011). These new areas are entirely dependents on nearby poles, which usually results in social exclusion and often increases the cost of infrastructure to the city. (Amado 2018).

Based on the analyzed processes, it was also observed that there was no standardization in the requirements. In their initial requests, the entrepreneurs presented few mitigating measures leaving the city to make demands. As a result, the ventures' spending on environmental measures was more or less equal to the sum of the initial propositions and the requirements made by the licensing agency.

The lack of a base document to guide the development and subsequent analysis of the processes also increased the time spent by entrepreneurs to license their ventures, which took 14 months on average, although this discussion is not the focus of this analysis.

\section{FINAL CONSIDERATIONS}

The five analyzed allotments indicated five major environmental impacts: soil compaction and erosion, emission of air pollutants, alteration of original vegetation and generation of construction waste. The latter was indicated only in one of the projects. None fulfilled all legislation aspects. The biggest obstacle observed was the lack of standardization in the process required by the City Hall, which culminated in projects with different characteristics.

In general, the complexity of the addressed topic is determined by the administrative and legal aspects, training and even awareness of those involved in the analysis of environmental issues in the development process. There is also a lack of connection between the planning instruments and their practical application in the environmental licensing of subdivisions.

For further studies of impact assessment projects, it is necessary to move forward in the discussions related to urban environmental sustainability and standardizing the possible actions, not only in the municipality of Governador Valadares but in the entire country. Standardization, however, must maintain a margin for adjustments related to the characteristics of each location in order to facilitate the licensing processes, not to plaster. Therefore, it is important to create a manual containing minimal information to be addressed in environmental impact assessment to assist managers and entrepreneurs, optimizing and streamlining the process.

Despite the challenges outlined before, the collaboration between public power, engineers, scientists and involved citizens can result in environmental impact assessments with less prejudice and more benefits for all. Therefore, further studies should be carried out to understand how to make this participation effective.

Another topic that needs to be explored is the impact assessment of allotments during the operation phase, which includes the construction at each lot, in order to understand if there is a cumulative impact that should be addressed during the preliminary studies.

\section{REFERENCES}

Alberto J.A. (2009). Geography and urban growth. Landscapes and environmental problems. Digital Geography Journal, 11, (in Spanish with English summary), DOl: 10.30972/geo.6112840.

Amado M. (2018). Wall-Up: Method for the regeneration of settlements and housing in the Developing World. Sustainable Cities and Society, 41, 22-34, DOI: 10.1016/j.scs.2018.05.024.

Amorim M.M.A., Assunção G.H.O., Dias A.C., Guedes G.R. (2018). Social representation of Rio Doce and its floods in Governador Valadares/ Brazil. Development and environment, 49, (in Portuguese with English Sumary), DOl: 1 0.5380/dma.v49i0.57707.

Arretche M. (2006). A contribution to making less naive comments. In: Barreira, M. C. R. N.; Carvalho M.C.B. (Orgs.). Trends and perspectives in the evaluation of social policies and programs. São Paulo: IEE/PUC, 43-56. (in Portuguese with English Summary).

Braga R. (2013). Transfer of environmental costs in implementation of closed subdivisions in the city of Piracicaba-SP. Geography Notebook, 23 (39), 98-115. (in Portuguese with English Summary).

Brazilian Institute of Geography and Statistics (2020). Census 2010. Available at: http://www.ibge.gov.br. [Accessed 12 Jan. 2020]. (in Portuguese with English Summary).

Agência Nacional De Águas. (2017) Sewage atlas of watershed depollution. Available at: http://atlasesgotos.ana.gov.br/. [Accessed 23 Oct. 2019]. (in Portuguese with English Summary).

Basic Sanitation Company of the State of São Paulo (SABESP) (2017). Technical Standard Sabesp NTS 181. Dimensioning of the building water branch, easel and hydrometer - first connection. 4 review. São Paulo. Available at: http://www2.sabesp.com.br/normas/nts/NTS181. pdf. [Accessed 20 Feb. 2020]. (in Portuguese with English Summary).

Brazil (1979). Federal Law n. 6.766, 19 dec. 1979. Provides on the Urban Land Installment and provides other measures. Brazilian Law Collection, Brasília, 7, 172. (in Portuguese with English Summary).

Brazil (2001). Federal Law n. 10.257, 10 Jul. 2001. Regulates arts. 182 and 183 of the Federal Constitution, establishes general guidelines for urban policy and takes other measures. Official Journal of the Union. Brasília, DF. (in Portuguese with English Summary).

Brazil (2002). National Environment Council.Resolução CONAMA no. 307, de 5 de julho de 2002. Establishes guidelines, criteria and procedures for the management of construction waste. Ministry of the Environment: CONAMA. Official Journal of the Union. Brasília, DF: Official Press. (in Portuguese with English Summary).

Brazil (2006). National Environment Council.Resolução n. 369, 28 mar. 2006. Provides for exceptional cases of public utility, social interest or low environmental impact, which enable the intervention or suppression of vegetation in the Permanent Preservation Area-APP. Official Journal of the Union. Brasília, DF: Imprensa Oficial. (in Portuguese with English Summary). 
Brazil (2012a). National Environment Council. CONAMA Resolution no. 448, 18 jan. 2012. Changes arts. 2nd, 4th, 5th, 6th, 8th, 9th, 10th and 11 th of Resolution No. 307, of July 5, 2002, from CONAMA. Official Journal of the Union. Brasília, DF: Imprensa Oficial. (in Portuguese with English Summary).

Brazil (2012b). Federal Law n. 12.651, 25 may 2012. Forest Code. Official Journal of the Union. Brasília, DF: Official Press. (in Portuguese with English Summary).

Capodaglio A.G. (2017). Integrated, decentralized wastewater management for resource recovery in rural andperi-urban areas. Resources, 6 (22), DOI: 10.3390/resources6020022.

Costa H.S.M. (1999). Sustainable urban development: a contradiction of terms? Brazilian Journal of Urban and Regional Studies, 2, (in Portuguese with English Summary), DOl: 10.22296/2317-1529.2000n2p55.

Endreny T.A. (2018). Strategically growing the urban forest will improve our world. Nature Communications, 9 (1160), DOI: 10.1038/ s41467-018-03622-0.

European Union (2000). Proposal for a Directive of the European Parliament and of the Council Amending Directive 2000/60/ CE establishing a framework for Community action in the field of water policy, as regards the implementing powers conferred on the Commission /* COM/2006/0921 final - COD 2006/0297. Available at: https://eur-lex.europa.eu/legal-content/EN/TXT/HTML/?uri=CELEX:520 06PC0921\&qid=1614186550172\&from=EN [Access 24 Feb.. 2021].

Fardin S.C.S.G., Fardin Henrique D., Fardin Hugo D. (2018). Urban land regularization in social interest areas: law and apllication of environmental instruments. Forest Cience, 28 (2), 854-862, (in Portuguese with English Summary), DOI: http://dx.doi. org/10.5902/1980509832108.

Fischer J., Manning A.D., Steffen W., Rose D.B., Daniell K., Felton A., Garnett S., Gilna B., Heinsohn R., Lindenmayer D.B., Macdonald B., Mills F., Newell B., Reid J., Robin L., Sherren K., Wade A. (2007). Mind the sustainability gap. Trends Ecol Evol, 22(12), 621-624, DOI: 10.1016/j. tree.2007.08.016.

Genovez P.F., Vilarino M.T.B., Superbi R. (2012). Riverside populations and the urbanization process: the historical horizon of the floods in Governador Valadares from the Diário do Rio Doce newspaper. In: Regional Meeting (ANPUH-MG), XVIII, 2012. Anais... Mariana, MG. 2012. Available at: http://www.encontro2012.mg.anpuh.org/resources/anais/24/1340661306_ARQUIVO_PopulacoesRibeirinhaseoprocessodeurb anizacao.pdf>. [Accessed 18 Oct. 2019]. (in Portuguese with English Summary).

Governador Valadares City Hall (2013). Complementary law n. 167, 27 nov.2013. Institutes the civil construction and bulky waste management plan and takes other measures. (in Portuguese with English Summary). Available at: https://transparencia.valadares.mg.gov. br/detalhe-da-legislacao/info/lei-complementar-167-2013/900 [Accessed 25 Feb. 2021].

Governador Valadares City Hall (2014a). Complementary law n 178, 04 Sep. 2014. Provides for the parceling of land for urban purposes in the municipality of Governador Valadares and provides other measures. (in Portuguese with English Summary). Available at: https://www. valadares.mg.gov.br/detalhe-da-legislacao/info/lei-complementar-178-2014/913 [Accessed 25 Feb. 2021].

Governador Valadares City Hall (2014b). Complementary law n 187, 30 dec. 2014. Provides for environmental licensing and intervention in APP. (in Portuguese with English Summary). Available at: https://www.valadares.mg.gov.br/detalhe-da-legislacao/info/leicomplementar-187-2014/308 [Accessed 25 feb. 2021].

Governador Valadares City Hall (2015). Municipal Basic Sanitation Plan - Diagnosis of the provision of Basic Sanitation, Urban Cleaning and Solid Waste Management services. (in Portuguese with English Summary). Available at: https://transparencia.valadares.mg.gov.br/abrir_ arquivo.aspx/DOCUMENTO_1?cdLocal=2\&arquivo=\%7BA58CCB07-56CC-5B4E-B867-23EDDAAE22BD\%7D.pdf [Accessed 25 Feb. 2021].

Grostein M.D. (2001). Metropolis and urban expansion: the persistence of «unsustainable» processes. São Paulo in Perspective, 15 (1), (in Portuguese with English Summary), DOI: 10.1590/S0102-88392001000100003.

Ho P. (2001). Who owns China's land? Policies, property rights and deliberate institutional ambiguity. China Quarterly, 166, 394-421, DOI: $10.1017 /$ S0009443901000195.

Jorsaraei A., Gougol M., Van Lier J.B. (2014). A cost effective method for decentralized sewage treatment. Process Safety and Environmental Protection, n. 92, DOI: 10.1016/j.psep.2013.04.001

Lollo J.A., Rohm S.A. (2009). Allotments and impact assessment mechanisms in Brazil. Holos Environment, 9 (1), 145-166, (in Portuguese with English Summary), DOI: 10.14295/holos.v9i1.176.

Mineral Resources Research Company (2004). Definition of the floodplain in the city of Governador Valadares. Final Technical Report. Belo Horizonte. (in Portuguese with English Summary).

Monkkonen P. (2013). Urban land-use regulations and housing markets in developing countries: Evidence from Indonesia on the importance of enforcement. Land use policy, 34, 255-264, DOI: 10.1016/j.landusepol.2013.03.015.

Morgan R.K., Hart A., Freeman C., Coutts B., Colwill D., Hughes A. (2012). Practitioners, professional cultures, and perceptions of impact assessment. Environmental Impact Assessment Review, 32 (1), DOI: 10.1016/j.eiar.2011.02.002.

Mullaney J., Lucke T., Trueman S.J. (2015). A review of benefits and challenges in growing street trees in paved urban environments. Landscape and Urban Planning, 134, 157-166, DOI: 10.1016/j.landurbplan.2014.10.013.

Pereira J.H. (2015). Analysis of environmental impacts generated by the implementation of high-standard closed subdivisions. $131 \mathrm{f}$. Dissertation (Master's) - State University Paulista Júlio de Mesquita Filho. Engineering College, 70 (in Portuguese with English Summary). Available at: https://repositorio.unesp.br/handle/11449/124503 [Accessed 25 Feb. 2021]

Polidoro M., Lollo J.A., Barros V.F. (2011). Environmental impacts of urban sprawl in Londrina, Paraná, Brazil. Journal of Urban and Environmental Engineering, 5(2), 73-83, DOl: 10.4090/juee.2011.v5n2.073083.

Raworth K. (2012). A safe and just space for humanity: can we live within the doughnut? Oxfam Discussion Papers. Available at: http:// docserver.ingentaconnect.com/deliver/connect/oxpp/20530234/v8n1/s1.pdf?expires=1572616646\&id=0000\&titleid=72010399\&checksu $m=D E 01 A C B 2211 B 58 C 795 B F 03 F E E 644 B 921$ [Access 5 Nov. 2019].

Ribeiro J.C.J., Vasconcellos Júnior J.B. (2020). Environmental impact assessment: origin, standardization and (in) effectiveness within the scope of Brazilian environmental licensing processes. International Journal of Environmental Law, XI (25),133-154. (in Portuguese with English Summary), DOI: 10.1590/1809-4422asoc235r2v2022017.

Roedel T., Dias L.O. (2018). Environmental impacts of subdivisions: analysis of simplified environmental studies of normative instruction n. 04 of FUNDEMA, in Brusque - SC. Diffuse Rights Magazine, 70. (in Portuguese with English Sumary).

Rotaru C.S., Manciulea, I.; Draghici, C. (2019). Effect of environmental monitoring on the environmental legislative process. Environmental Engineering and Management Journal, 18 (8), 1843-1847.

Santos E.T., Haddad E.A. (2014). Mapping of potential economic losses from flooding points in the city of São Paulo, $2008-2012$. Environment and Society, XVII (4), (in Portuguese with English Summary), DOI: 10.1590/1809-4422ASOC969V1742014. 
Silveira S.J., Oliveira F.H., Schuch F.S. (2020). Minimum green area for sustainable subdivisions according to the hydrological cycle. Architecture Magazine, 16(1), (in Portuguese with English Summary), DOl: 10.4013/arq.2020.161.02.

Spolidorio P.C.M. (2017). The negotiated allocation of water as a responsive regulation strategy. Journal of Law and Regulation, 3(1), 183198. (in Portuguese with English Sumary).

Stanganini F.N. \& Lollo J.A. (2018). The growth of the urban area of São Carlos / SP city between the years 2010 and 2015: the advance of environmental degradation. city. Brazilian Journal of Urban Management, 10 (Suppl. 1), 118-128, (in Portuguese with English Sumary), DOI: 10.1590/2175-3369.010.supl1.ao14.

Tamburino L., Baldassare G., Vico G. (2020). Water management for irrigation, crop yield and social attitudes: a socio-agricultural agentbased model to explore a collective action problem, Hydrological Sciences Journal, DOl: 10.1080/02626667.2020.1769103.

Tavanti D.R., Barbassa A.P. (2012). Analysis of low-impact and conventional urban developments. Brazilian Journal of Water Resources, 17(4), (in Portuguese with English Sumary), DOl: 10.21168/rbrh.v17n4.p17-28.

Tucci C.E.M. (2009). Integrated urban water management in large cities: a practical tool for assessing key water management issues in the large cities of the developing world. Draft paper prepared for World Bank.

United Nations (2012). How to build more resilient cities: Guide for Local Public Managers. Available at: https://www.unisdr.org/ files/26462_guiagestorespublicosweb.pdf. [Accessed 11 Nov. 2019]. (in Portuguese with English Sumary).

Xavier L.Y., Grilli N.M., Carmo A.B., Jacobi P.R., Turra A. (2019). The importance of post-normal science in environmental impact assessments. In: P. R. Jacobi et al., Ed. Post-Normal Science expanding the dialogue with society in the face of contemporary environmental crises, 1 st ed. São Paulo: USP School of Public Health, 47-69, (in Portuguese with English Summary), DOI: 10.11606/9788588848375. 